\title{
共同堆肥化処理施設の経営改善に関する一考察
}

\author{
駄田井 久（岡山大学大学院） \\ 佐藤 豊信（岡山大学農学部） \\ 星野敏（岡山大学農学部）
}

\section{1.はじめに 課題と目的}

我が国の畜産は, 戦後の経済発展の中で急激な発展 を遂げてきた。 しかし，畜産農家の規模挔大は，農地 の新たな取得は行われずに, 輸入飼料に依存した加工 畜産として発展してきた. そのために，我が国の畜産 は土地から切り離され, 施設依存型畜産として特徴づ けられている．また，近年の海外・国内の競争が激化 してくる中で, 畜産農家は生き残りの手段として頭数 の増加による規模拡大を選択した. その結果として畜 産農家総数は減少していているが，畜産農家一戸あた りの飼育頭数は增加傾向にある. その結果として, 畜 産農家から排出される家畜粪尿の集中・偏在化の問題 が顕著になってきている. 家畜糞尿は適切に処理され 農耕地に還元されると有機質肥料として貴重な資源で あるが, 野積み・素倜投棄等, 不適切に処理されると 窒素過多による地下水污染, 作物の生育障害等の外部 不経済を発生させる．また，近年では輸入飼料に含ま れる外来雑草の繁殖といった新たな外部不経済の発生 もみられる.

この様な動向を受けて，「環境 3 法」が平成 11 年度 から施行され家音䔬尿の適切な処理二堆肥化処理を義 務づけた. しかし, 個々の畜産農家が堆肥化処理を行 うことは, 労働力の不足, 堆肥化処理施設に新たな投 資が必要になる等の理由により資尿処理が音産経営そ のものを圧迫する危険性がある．この様な問題に対す る解決策の一つとして, 地域内の共同堆肥化処理施設 を利用することにより, 畜産農家の経営から粪尿処理 部門（堆肥生産販売部門）を切り離すことが举げられ る. しかしながら, 現状では共同堆肥化処理施設の大 半が赤字経営である.このままでは, 施設の維持・存 続が不可能であり, 共同堆肥化処理施設の経営改善が

\begin{abstract}
必要不可欠である.
耕種農家が堆肥を購入する際には, 品質が同じであ る堆肥であれば，地域内で生産された堆肥を優先して 購入するわけでなく, 価格の低い堆肥を購入すると考 えられる. そのために, 共同堆肥化処理施設の経営改 善には堆肥生産費の削减が最も有効であると考えられ る注1）。本論文の目的としては，(1)共同堆肥化処理施 設の堆肥生産費用曲線を導出, (2)堆肥生産費用の削减 のために有効である施策に関する考察, (3)岡山県内の 共同堆肥化処理施設を対象にその施策によってどの程 度の費用削減が可能であるかを明らかにする.
\end{abstract}

\section{2. 共同堆肥化処理施設の収支状態}

全国の共同堆肥化処理施設の経営状況を, 運営主体 別·資本金別（初期の固定資本投資額）に見てみると, 赤字経営の施設には以下の椂な特徵があげられる（表 1参照). (1)農協, 市町村・公社が運営主体である施設 (2)資本金額が大きな施設（資本金額 5 千万円以上）で ある．一方で黒字経営である施設では(1)個人・法人が 運営主体である施設, (2)資本金額が小さな施設（資本 金額 1 千万円未満）の施設が中心となっている.

そこで, 岡山県内の第 3 セクター・JA が運営主体で ある 7 力所の共同堆肥化処理施設を今回の分析対象之 する．それぞれの施設における，概要は以下のとおり である. 施設が対象としている畜種は乳用牛十鶏 : 3 力 所, 肉用牛十鷄: 2 力所, 肉用牛十豚: 1 力所, 肉用牛十

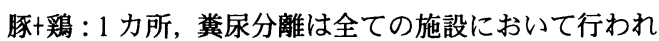
ておらず，施設に持ち込まれる粪尿の水分含有率は， $60 \%$ ８0\%である.

表 1.共同堆肥化処理施設の経営状況

単位 : 数 $\%$

\begin{tabular}{|c|c|c|c|c|c|c|c|c|c|}
\hline & \multicolumn{4}{|l|}{ 運営主体 } & \multicolumn{5}{|l|}{ 資本金 } \\
\hline & 回答数 & 個人·法人(\%) & 農協(\%) & 市町村·公社 $(\%)$ & 回答数 & 1千万末満(\%) & 〜 3千万(\%) & 〜 5千万(\%) & 5千万以上(\%) \\
\hline 全体 & 96 & 52.6 & 36.8 & 10.5 & 83 & 40.2 & 15.9 & 13.4 & 30.5 \\
\hline 黒字経営 & 37 & 67.6 & 21.6 & 10.8 & 33 & 45.5 & 13.4 & 9.1 & 24.2 \\
\hline 収支ゼロ & 22 & 59.1 & 31.8 & 90.1 & 22 & 50.1 & 9.1 & 18.2 & 18.1 \\
\hline 赤字経営 & 34 & 32.4 & 58.8 & 11.8 & 27| & 25.9 & 18.2 & 14.8 & 48.1 \\
\hline
\end{tabular}

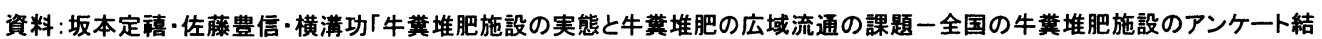




\section{3. 共同堆肥化処理施設の堆肥生産費用曲線}

（1）共同堆肥化処理施設の䔬尿処理の流れ

細部（機械の種類・発醅方法等）は個々の施設によ って異なるが，大まかな糞尿処理の流れは，図 1 に示 すとおりである. 畜産農家から持ち込まれた糞尿は, 水分調節材が添加され発醳機によって擋汼され乾燥・ 一次発醅が行われる. その後, 堆肥舎に移され切り返 し・堆積が行われ完熟堆肥となる. 最終的にはバラ. 袋詰めの形で製品として出荷される ${ }^{2)}$.

また, 施設における糞尿処理能力は, 一次発酵を行 う発酻機の能力と, 堆積が行われる堆肥舎の面積によ って決定される.

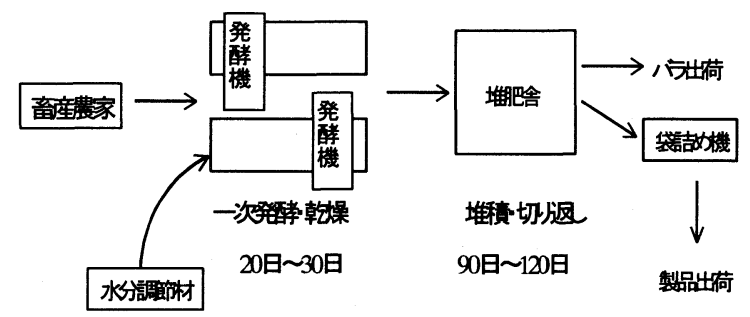

（2）堆肥生産费用関数の特徴

一般的に生産費用関数は固定費と変動費で構成され, 変動費部分は比例費用と不比例費用に分けられる．比 例費用は, 生産量の增加に従って比例的に增加してい く費用であり，不比例費用は一般的には生産量の増加 に従って聥增的に增加していく．この不比例費用が存 在するために, 限界費用は派增的增加関数として描か れる.

堆肥生産の生産関数も, 固定費用部分と変動費用部 分で構成される. 固定費用部分は, 堆肥舎・発酵機・ 袋詰め機・労働費 (一般的に共同堆肥化処理施設では, 1〜2 名の職員が常時雇用されている.) で構成される. 変動費用部分は, 水分調節材費 - 光熱費 · 燃料費 - 袋 代等で構成される. いずれも堆肥生産量の增加に従っ て比例的に増加していくものである. そのために変動 費用部分は比例費用のみで構成される.

また, 前述のように施設の糞尿処理能力（堆肥生産 能力）は, 発酵機の能力と堆肥舎の面積で決定される. 能力の限界以上の堆肥生産を可能にするためには, 新 たに発醳機・堆肥舎を設置する必要がある.この様に, 堆肥生産に関してはある生産量（能力の限界点）を超 えた時点で新たなる固定資本投資が必要となり，技術 の不可分性が存在する.

この様な堆肥生産の特徵（1)変動費用部分が比例費
用のみで構成される. (2)技術の不可分性が存在する.) により堆肥生産費用関数は以下の様な形になる.

総費用 $\quad: \mathrm{TC}=\mathrm{C}+\mathrm{t} \times \mathrm{T}$

平均費用 $: A C=C / T+t$

限界費用: $M C=\mathrm{t}$

$(\mathrm{C}:$ 固定費用, $\mathrm{t}:$ 比例費用, $\mathrm{T}:$ 堆肥生産量)

\section{（3）生産費用曲線}

以上の梯な共同堆肥化処理施設における堆肥生産の 特徵により,生産費用曲線は図 2 の様な形で描かれる.

総費用が固定費用と比例費用のみで構成されるため に, 限界費用曲線は横軸に対して平行な直線であり, 平均費用曲線は限界費用曲線に漸近していく直角双曲 線なる.

また, 技術の不可分性が存在するために, 平均費用 曲線は階段状となる. 堆肥生産量の増加に従って平均 表曲線は限界費用曲線に渐近していくが, 処理限界量

（T*）を少しでも超えると，新たに固定資本投資が必 要となるために, 平均費用曲線が上方に移動する. さ らに, 堆肥生産量が増加していき, 次の処理限界量 $\left(\mathrm{T}_{2}\right)$ を少しでも超えるとさらなる固定資本投資が必要とな り, 平均費用曲線はさらに情報に移動する. この様に して, 共同堆肥化処理施設の堆肥生産長期平均費用曲 線は, 図 2 の太線の様な形となる.

\section{図 2 長期の堆肥生産費用曲線}

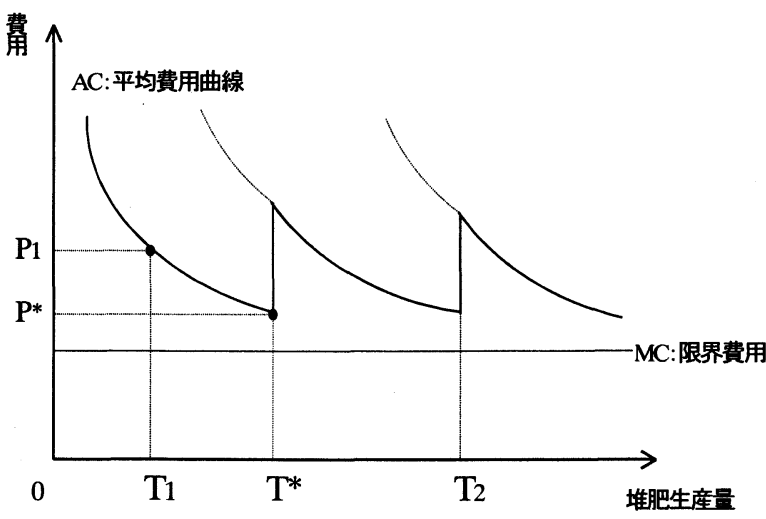

\section{4，堆肥生産費用削減の方策}

前節の堆肥生産費用関数·堆肥生産費用曲線を基に, 共同堆肥化処理施設における堆肥生産費用削減の方策 についての考察を行う.

\section{(1) 稼動率の向上}

共同堆肥化処理施設の堆肥生産においては, 技術の 不可分性が存在する. しかし, 変動費用部分が比例費 用のみで構成されるために, 処理能力限界よりも少な 
い生産量では生産量を增加することによって平均費用 の削減は可能である. 図 2 において, 現在の生産量が $\mathrm{T}_{1}$, 堆肥生産の平均費用が $\mathrm{P}_{1}$ である. 生産量を処理能 力の限界 T*まで增加させることにより平均費用を $\mathrm{P} *$ まで削減することが可能となる.

この様に, 現在の堆肥生産量が処理限界能力以下で ある時は, 生産量を增加させ施設の稼働率を向上させ ることで, 堆肥生産費用の削減が可能である.

\section{（2）限界費用の削減}

同一の規模の施設, 同一の堆肥生産量においても, 限界費用（此例費用）の大きさによって堆肥生産の平 均費用は差が生じる。

図 3 は, 同じ規模の施設で同量の生産を行っている 場合である. 左側の施設は限界費用が大きく, 右側の 施設は小さくなっている. $\left(\mathrm{MC}_{1}>\mathrm{MC}_{2}\right)$ 結果として, 同 量の生産（T*）を行っても限界費用の大きな施設の平 均費用が小さな施設と比較すると大きくなっている $\left(\mathrm{P}_{1}>\mathrm{P}_{2}\right)$. この様に, 限界費用部分を削减することに より堆肥生産平均費用の削减が可能である.
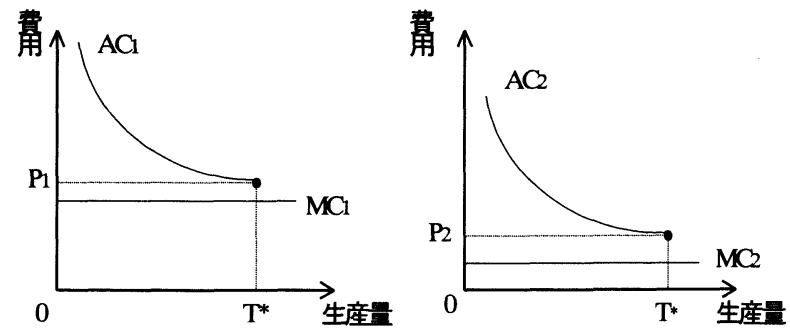

图 3 限界費用と平均費用の関係

以上，共同堆肥化処理施設における堆肥生産費用の 削減には(1)施設の稼働率を上昇させることにより, 固 定費用部が占める割合を小さくする. (2)限界費用の削 减を行う．の 2 つの方法が有効である.

\section{5，堆肥生産費用削減の可能性}

前節で考察した堆肥生産費用削减方法を実施した場 合, どの程度の生産費用削減が可能であるかを明らか にする. 分析対象は岡山県内の第 3 セクター・JAが運 営主体である 7 力所の共同堆肥化処理施設を取り上げ る. いずれの施設も運営状態は赤字であり, 経営の改 善が急務であるとされている.

\section{（1）堆肥生産費用の中身}

岡山県内の共同堆肥化処理施設（第 3 セクター・JA が運営主体の 7 力所) の堆肥生産費用の平均は 19,700 円である. 固定費部分は減価償却費と労働費であり， 合計 13,055 円/トンである (表 2 参照). 今回の対象施
設においても職員は年間雇用であり, 労働費は堆肥生 産量とは関係なく固定的である．（減価償却費につい ては，50\%圧縮計算を行っている．施設・機械に対する 補助金率が 50\%であるからである.）また，変動費用部 分は, 水分調節材費, 光熱費 - 燃料費, 修縹費であり, その合計額は 4,925 円/トンである. 堆肥生産量が增加 するに従って, 故障も比例的に增加する. そのために, 修繥費用も堆肥生産量の增加に従って比例的に增加し ていくと考えられる. 固定費用部分の堆肥生産費用に 占める割合は，約 $67 \%$ でり，変動費用部分が占める 割合は，約 25\%である.

表 2．堆肥生産費用（堆肥 1 ケッあたり）

\begin{tabular}{c|r|r} 
& 費用 $(円)$ & 構成比 $(\%)$ \\
\hline \hline 減価償却費 & 7,694 & 39.02 \\
学動費 & 5,361 & 27.19 \\
水分調節材費 & 1,763 & 8.94 \\
光熱費·燃料費 & 2,030 & 10.30 \\
修繥費 & 1,132 & 5.74 \\
その他 & 1,736 & 8.81 \\
\hline 計 & 19,716 & 100.00 \\
\hline
\end{tabular}

資料：岡山県畜産会「公共堆肥センターの管理と運営」

(2) 稼譈率向上による堆肥生産費用削減

今回の分析対象である共同堆肥化処理施設の稼働率 は, 7 力所平均で $54 \%$ である ${ }^{3)}$. 最も稼働率が高い施

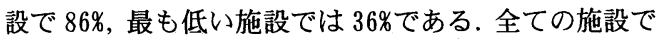
稼働率を $100 \%$ にする事により，固定費部分を約 4,000 円 ノトン，平均費用を約 8,500 円 ノトまで削減すること が可能である.

\section{（3）変動費用削隇による堆肥削減費用削隇}

岡山県内の優良事例（有限会社 T 堆肥センター）に おいては，(1)畜産農家が持ち込む粪尿の水分含有率を 65\%以下に徹底させる, (2)発醉温度のモニタリング基づ いて，適切な機械の運用を図ることにより水分調節材 費, 燃料費 - 光熱費の節約を行い, 変動費用分の削减 に成功している.この施設における変動費用部分は約 2, 400 円ノトンである.この様な変動費用削減の方法は, 特別な施設・機械，技術を必要としないために，新た な固定資本投資の必要性がない，そのために，今回対 象とした施設においても導入が容易であると考えられ る.

以上のように, 岡山県内の第 3 セクター・JAが運営 主体である 7 力所の共同堆肥化処理施設において, 稼 働率を $100 \%$ に，堆肥生産費用に占める固定費部分の 割合を小さくすると同時に, 変動費部分の削減（持ち 込み粪尿の水分含有率の規制 - 発醭温度のモニタリン グ）を同時に行うことにより，現状の堆肥生産費用約 
19,000 円ノトンを約 6,600 円ノトン（稼働率向上による削 减後の固定費 : 約 4000 円 $/$ ト削減後の変動費用部 分: 約 2400 円 $/$ ト) まで削减可能であることが明らか になった.

\section{6. 堆肥生産費用削減の今後の課題 (1) 稼儌率上昇の課題}

施設の稼働率を上げるためには，音産農家の持ち込 む糞尿量を增加させる必要がある. 畜産農家にとって, 共同堆肥化処理施設を利用することは十分に経済合理 的な行動であるが注 ${ }^{2)}$, 共同堆肥化処理施設を利用して 糞尿処理を行っている畜産農家の割合は低いのが現状 である. 施設の利用料金等の経済的な要因以外にも, 畜産農家の共同堆肥化処理施設利用率に影響を与えて いる外的な要因が存在すると考えられる．今後，施設 の利用率を上げるためにはこれらの外的要因の分析 （糞尿の持ち込みのための道路が整備されているか 等) が必要である.

また，現在の施設規模では施設の存在する市町村内 の畜産農家から排出される糞尿だけでは稼働率 $100 \%$ の達成は不可能である社 31 . 稼働率 $100 \%$ を達成するた めには, 近隣市町村の音産農家から翼尿を持ち込んで もらう必要がある. そのための, 糞尿の集配サービス システムの構筑等が必要になる.（霬尿の集配に必要 となるコストと，稼働率の向上による堆肥生産費用削 減可能額との比較が必要である.)

(2) 限界费用削減の課題

限界費用削減のためには，畜産農家が持ち込む粪尿 の水分含有率を一定水準以下に徹底する必要がある. そのためは, 持ち込む䔬尿水分含有率に応じた施設の 利用料金を設定するのが最も効果的である. しかし， その様な料金設定は畜産農家の行動に影響を与え，施 設に持ち込まれる粪尿量にも影響を与えると考えられ る. 施設の利用料金の変化に対する畜産農家の行動の 分析が必要である.

\section{(3) 長期的な課題}

現在の施設を利用した場合は, 約 6000 円 ノトシまでの 堆肥生産費用の削减が可能である. しかし, 今後, 共 同堆肥化処理施設が利益を上げるためには，さらなる 堆肥生産費用の削減が必要となる，そのためには，施 設を再整備（减価償却の終了した施設を廃止し，新た な施設の整備を行う等) する必要がある. 共同堆肥化 処理施設における堆肥生産においては, 技術の不可分 性が存在するために一定水準以下の生産費用削減は不 可能である, 畜産農家の粪尿持ち込みコストが小さく
なる等の理由により，小規模の施設を多数整備した方 が有利である. 一方で, 製品である堆肥の保管・輸送, 堆肥販売の営業活動等には「規模の経済」が働き，大 規模な施設の方が有利であると考えられる.この様に， トレードオフの関係が存在すると考えられる. その他 に水分調節材（オガクズ・バーク等）の入手には，立 地条件が大きく影響する. 原料である粪尿の運送コス ト，水分調節材の入手の容易さ，製品の堆肥運送コス 卜等を含めて, どこに，どの程度の規模の施設を整備 するかの検討が必要である.

注

1）共同堆肥化処理施設の経営改善の方法として, 高 品質の堆肥を高い価格で販売することも考えられ る. そのためには，新たな技術の取得，施設・機 珹の更新が必要となり,短期的には不可能である. そのために，今回は堆肥生産費用の削減に関する 施策のみを考察する。

2）線形計画法を用いた酪農経営モデル(「旭川流域畜 産環境基本調查」：中国四国農政局（1996)）によ ると, 粪尿処理制約のシャドープライスは, 22,683 円／賴尿 1 トンであった．また，今回対象とした共 同処理施設の施設利用料金は 800 円〜 1700 円 $/$ r である。

3）「1995 年度農業センサス」をもとに, 共同堆肥化 処理施設の存在する各市町村の乳牛・肉牛の飼育 頭数から計測される翼尿排出量と各施設の糞尿処 理限界量を比較した結果である.

\section{参考文献・引用文献}

1）坂本定禧・佐藤豊信・横溝功「牛糞堆肥施設の実 態と牛豪堆肥の広域流通の課題一全国の牛䔬堆肥 施設のアンケート結果を中心に一」『農林業問題 研究』別冊・地域農林経済学会大会報告論文集第 6 号 1998 年 3 月 $\quad p p 37 \sim 47$

2）社団法人岡山県畜産会『公共堆肥センターの管理 と運営』平成 11 年 3 月

3）佐藤和久「公的堆肥センターにおける堆肥生産費 の実態と生産費低減対策」 